\title{
Additive Effects of Postharvest Calcium and Heat Treatment on Reducing Decay and Maintaining Quality in Apples
}

\author{
William S. Conway \\ Beltsville Agricultural Research Center, Agricultural Research Service, U.S. Department of Agriculture, \\ Beltsville, MD 20705 \\ Carl E. Sams \\ Department of Plant and Soil Science, University of Tennessee, Knoxville, TN 37901 \\ Chien Yi Wang and Judith A. Abbott \\ Beltsville Agricultural Research Center, Agricultural Research Service, U.S. Department of Agriculture, \\ Beltsville, MD 20705
}

Additional index words. $\mathrm{CaCl}_{2}$, Malus domestics, Botrytis cinerea, pressure infiltration

\begin{abstract}
Golden Delicious' apples (Malus domestics Borkh.) were treated with heat or $\mathrm{CaCl}_{2}$ solutions or a combination thereof to determine the effects of these treatments on decay and quality of fruit in storage. Heat treatment at 38C for 4 days, pressure infiltration with $2 \%$ or $4 \%$ solutions of $\mathrm{CaCl}_{2}$, or a combination of both, with heat following $\mathrm{CaCl}_{2}$ treatment affected decay and firmness during 6 months of storage at $0 \mathrm{C}$. The heat treatment alone reduced decay caused by Botrytis cinerea (Pers.:Fr.) by $\approx \mathbf{3 0 \%}$, while heat in combination with a2\% $\mathrm{CaC1}_{2}$ solution reduced decay by $\approx 60 \%$. Calcium chloride solutions of $2 \%$ or $4 \%$ alone reduced decay by $40 \%$ and $60 \%$, respectively. Heat treatments, either alone or in combination with $\mathrm{CaC1}_{2}$ treatments, maintained firmness $(80 \mathrm{~N})$ best, followed by fruit infiltrated with $2 \%$ or $4 \%$ solutions of $\mathrm{CaCl}_{z}$ alone $(70 \mathrm{~N})$ and the nontreated controls $(66 \mathrm{~N})$. Instron Magness-Taylor and Instron compression test curves show that heattreated fruit differed qualitatively and quantitatively from nonheated fruit. Heat treatment did not increase the amount of infiltrated $\mathrm{Ca}$ bound to the cell wall significantly, and a combination of heat treatment after $\mathrm{CaCl}_{2}$ infiltration increased surface injury over those fruit heated or infiltrated with $\mathrm{CaCl}_{2}$ solutions alone.
\end{abstract}

The use of synthetic chemicals to control plant diseases, especially for postharvest treatments, is becoming more restricted. Prestorage heat treatment of apples has been shown to affect fruit quality during storage beneficially. In 'Spartan' and 'Golden Delicious' apples exposed to 38C for 4 to 6 days and stored subsequently at $-1 \mathrm{C}$ for 4 to 7 months (Porritt and Lidster, 1978), fruit softening was suppressed and naturally occurring decay, largely due to Corticium and Penicillium sp., was reduced. Similarly, exposure at $40 \mathrm{C}$ for 2 to 4 days maintained firmness of stored 'Golden Delicious' fruit (Liu, 1978). Recently, Klein et al ( 1990) found that, for 'Anna' or 'Granny Smith' fruit, the best heat treatment was exposure to $38 \mathrm{C}$ for 4 days, and that a $\mathrm{CaCl}_{2}$ dip after the heat treatment augmented the effect of the heat treatment appreciably. In further work with 'Anna', Ca content generally did not increase as much from a dip following heat treatment as from a dip of nonheated apples (Lurie and Klein, 1992).

Increasing $\mathrm{Ca}$ in tissue of apple fruit alone also maintains firmness and reduces decay caused by Penicillium expansum Link, Botrytis cinerea, and Glomerella cingulata (Stoneman) Spauld. \& Schrenk (Conway and Sams, 1983; Sams and Conway, 1984; Conway et al., 1991).

In a recent study (Sams et al., 1993), 'Golden Delicious' apples were heat-treated at $38 \mathrm{C}$ for 4 days and then infiltrated with $4 \%$

Received for publication 23 Dec. 1992. Accepted for publication 5 June 1993. We express our appreciation to George A. Brown, Hilarine Repace, and William B. Beavers for valuable technical assistance. Use of a company or product name by the USDA does not imply approval or recommendation of the product to the exclusion of others that also maybe suitable. The cost of publishing this paper was defrayed in part by the payment of page charges. Under postal regulations, this paper therefore must hereby be marked advertisement solely to indicate this fact.
$\mathrm{CaCl}_{2}$ solutions before storage for 6 months at $0 \mathrm{C}$. Heat treatment and $\mathrm{Ca}$ infiltration maintained fruit firmness and reduced decay induced by inoculation with P. expansum after storage. However, heat treatment affected the surface of the fruit so that there was a smaller increase in $\mathrm{Ca}$ in heated than in nonheat-treated fruit. Heat treatment, however, caused no injury.

There is increasing evidence that polyamides maintain postharvest quality in fruits and vegetables. Temperature preconditioning inhibits the development of chilling injury with corresponding increases in polyamine levels in zucchini squash (Cucurbita pepo L.) (Kramer and Wang, 1989). Pressure infiltration of 'Golden Delicious' and 'McIntosh' apples with polyamides resulted in an immediate increase in firmness (Kramer et al., 1991). The effect of heat on polyamine levels is not known.

The objectives of our investigation were to determine the effect of infiltration of $\mathrm{CaCl}_{2}$ solutions into fruit before prestorage heat treatment on decay caused by the important postharvest pathogen Botrytis cinerea on firmness, cell wall-bound $\mathrm{Ca}$, polyamine levels, and fruit injury.

\section{Materials and Methods}

'Golden Delicious' apples were harvested in the preclimacteric stage (ethylene production was $<0.1 \mu \mathrm{l} \cdot \mathrm{liter}^{-1}$ and the climacteric rise in the $\mathrm{CO}_{2}$ level had not yet begun) from a commercial orchard and randomized. The apples were then treated in the following manner: 1) control (no treatment), 2) heat (4 days, 38C), 3) pressure infiltration of distilled water (3 rein, $103 \mathrm{kPa})$, 4) pressure infiltration with distilled water before heat treatment, 5) pressure infiltration with a $2 \%$ solution of $\left.\mathrm{CaCl}_{2}\left(\mathrm{w} / \mathrm{v}, \mathrm{CaCl}_{2} \cdot 2 \mathrm{H}_{2} \mathrm{O}\right), 6\right)$ pressure infiltration of a $2 \% \mathrm{CaCl}_{2}$ solution before heat treatment, 
7) pressure infiltration of a $4 \%$ solution of $\mathrm{CaCl}_{2}$, and 8) pressure infiltration of a $4 \%$ solution of $\mathrm{CaCl}_{2}$ before heat treatment. Fruit that were heat-treated were placed in tray-packed boxes with perforated polyethylene bags as liners prior to treatment. All fruit were stored at $0 \mathrm{C}$ following treatment. Apples were removed from storage after 6 months and tested for disease resistance, firmness, total $\mathrm{Ca}$ content, cell wall-bound $\mathrm{Ca}$ content, and polyamine content. The experiment was repeated.

Disease resistance. Twenty fruit from each treatment were wounded on two sides to a depth of $2 \mathrm{~mm}$ by pressing them down on the head of a nail $2 \mathrm{~mm}$ in diameter. The fruit were then immersed for $15 \mathrm{~s}$ in a conidial suspension (105 spores/ml) of $B$. cinerea. The area of decay was calculated from the means of the diameter of the width and length of lesions after 5 days at 20C.

Firmness measurements. Fruit were placed at 20C overnight. One tray of apples (20 fruit) from each replication of each treatment was measured with a manually controlled digital pressure tester (EPT-1; Lake City Technical Products, Kelowna, B.C., Canada). A second tray of similarly treated fruit was measured with a computer-controlled Instron (Canton, Mass.).

The EPT-1 was set in the Magness-Taylor (MT) mode and interfaced to a personal computer. Firmness (bioyield force) was measured at two opposite points on the equator of each fruit after removal of a 2-mm slice with a fixed-blade slicer.

Instron firmness measurements were made on two opposite manually pared surfaces using a standard 11.1-mm MagnessTaylor probe mounted on an Instron Universal Testing Machine interfaced with a personal computer to record force deformation curves (Abbott et al., 1982, 1984). Crosshead speed was 127 $\mathrm{mm} \cdot \mathrm{min}^{-1}$. Apples were measured immediately after storage at $0 \mathrm{C}$ in order to minimize changes during the time required for the Instron-MT measurements. The probe was programmed to travel 7.94-mm after contact with the flesh, regardless of the depth of actual penetration. Firm apples will probably be penetrated to the full $7.94 \mathrm{~mm}$, but dehydrated or spongy apples maybe deformed somewhat before actual penetration so that the probe does not penetrate the full amount. Complete force/deformation curves were recorded by the computer and analyzed later for maximum forces and other data (Abbott et al., 1984).

Compression tests. Immediately after the above measurements, two radial cylinders of apple flesh were removed at $90^{\circ}$ from the MT-I sites using a 15-mm-diameter cork borer. A 2.5 -mm slice of the cylinder, including the skin, was discarded and the next $10-\mathrm{mm}$ segment was tested by compressing between flat plates at 127 $\mathrm{mm} \cdot \mathrm{min}^{-1}$. The Instron was programmed to detect contact with the specimen, travel $7.5 \mathrm{~mm}$, reverse, and continue to collect force/ deformation data for another $2.5 \mathrm{~mm}$ (Abbott et al., 1982, 1984).

Total calcium content. A 2-mm layer of the peel and outer flesh of each fruit was removed with a mechanical peeler and discarded. The next $2 \mathrm{~mm}$ was cut with the peeler from four apples, and three such samples from each treatment were divided into two parts, one for total $\mathrm{Ca}$ analysis and the other for cell wall-bound $\mathrm{Ca}$ analysis. A small sample $(2 \mathrm{~g})$ of fresh tissue from each treatment was also used to determine total polyamine content. For total $\mathrm{Ca}$ analysis, the tissue was frozen immediately in liquid $\mathrm{N}_{2}$, freeze-dried, and ground. Dried material $(1 \mathrm{~g})$ was ashed, dissolved in $5 \mathrm{ml}$ of $2 \mathrm{~N}$ hydrochloric acid, and filtered. The samples were then analyzed for Ca content by plasma emission spectrometry.

Cell wall-bound calcium. About $100 \mathrm{~g}$ of apple tissue was homogenized in $100 \mathrm{ml}$ of cold $80 \%$ ethanol in a Waring blender and filtered through two layers of Miracloth (Calbiochem, La Jolla, Calif.). The residue was washed with $50 \mathrm{ml}$ of $80 \%$ ethanol and used for cell wall extraction following a modification of the procedure of Tong and Gross ( 1990). The residue was extracted in sequence in $100 \mathrm{ml}$ of $80 \%$ ethanol at $80 \mathrm{C}$ for 5 tin, rinsed in water, suspended in $200 \mathrm{ml} 20 \mathrm{~mm}$ Hepes buffer, pH 7.0, homogenized (Polytron, Brinkmann Instruments, Westbury, N. Y.) for 1 rein, and filtered through Miracloth at each stage. The residue was suspended in $100 \mathrm{ml}$ of Hepes buffer in a pressure bomb at 14.1 $\mathrm{MPa}$ for $10 \mathrm{~min}$ and then stirred for $60 \mathrm{~min}$ with $100 \mathrm{ml}$ phenol/ Tris, pH 7.5 (Huber, 1991), $10 \mathrm{~min}$ with $200 \mathrm{ml} 1$ chloroform: 1 methanol $(\mathrm{v} / \mathrm{v})$, and $10 \mathrm{~min}$ with acetone with filtration through sintered glass at each stage. The wall material was air-dried overnight and dried in vacuo over $\mathrm{P}_{2} \mathrm{O}_{5}$ at $40 \mathrm{C}$ for $48 \mathrm{~h}$. Cell wall $\mathrm{Ca}$ was then determined using the same procedures as for total $\mathrm{Ca}$.

Polyamine analysis. Polyamides in fresh apple tissue and in cell walls were determined by dansylation and HPLC separation according to the method of Kramer et al. (1989). Polyamides in the cell walls were analyzed after hydrolysis of $20 \mathrm{mg}$ of cell wall material with $2 \mathrm{ml}$ of $2 \mathrm{~N}$ trifluoroacetic acid at $100 \mathrm{C}$ for $2 \mathrm{~h}$. The. extracts were evaporated to dryness under $\mathrm{N}_{2}$ and redissolved in $5 \% \mathrm{HCIO}_{4}$ before analysis.

Injury rating. Forty fruit per treatment were rated visually by two observers for Ca injury at the time of the firmness and diseaseseverity ratings. The fruit were assigned a value of between 1 (severe injury) and 5 (no injury).

The experimental design was a completely randomized twofactor arrangement (two prestorage heat treatments $\times$ four infiltration treatments $\times$ three replications), with heat treatments being 0 or 4 days at $38 \mathrm{C}$ and infiltration treatments being none, distilled water $\left(0 \% \mathrm{CaCl}_{2}\right)$, and $2 \%$ or $4 \% \mathrm{CaCl}_{2}$. The effect of water infiltration vs. no infiltration was tested by contrasting treatments 1 and 2 against 3 and 4 . The effects of $\mathrm{CaCl}_{2}$ were tested by regression analysis of decay, MT firmness, tissue $\mathrm{Ca}_{2}$ or cell-wall Ca vs. Ca levels in treatments 3,5 , and 7 or 4,6 , and 8 .

\section{Results}

Decay. Heat-treated fruit (treatments 2 and 4) had 30\% less decay area due to $B$. cinerea than did the control (treatment 1$)($ Fig. 1). Water infiltration (treatment 3 ) had no effect on decay, but infiltration of a $2 \%$ solution of $\mathrm{CaCl}_{2}$ (treatment 5) resulted in

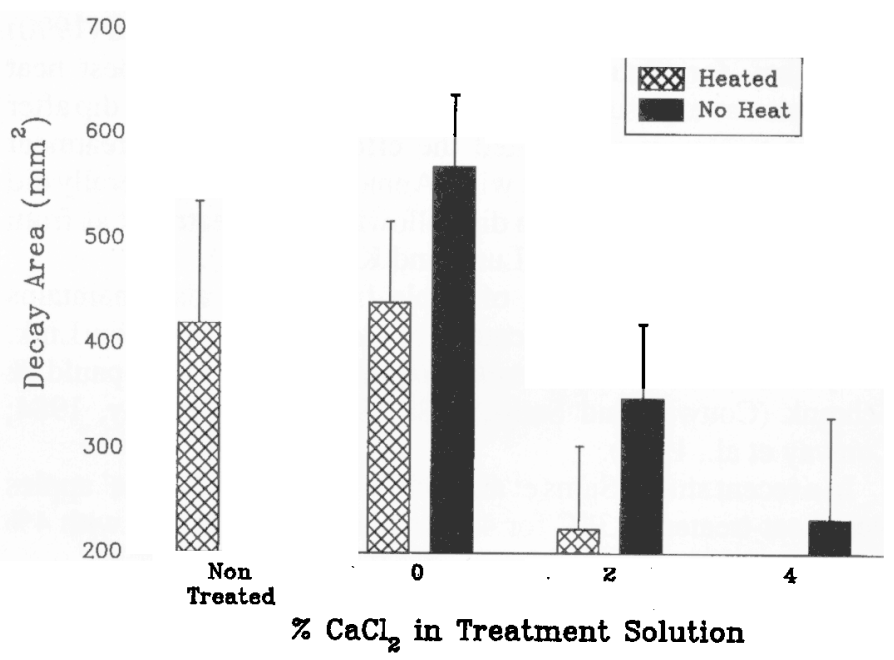

Fig. 1. Relationship between treatment and area of decay on 'Golden Delicious' apples. Fruit were either nontreated or pressure-infiltrated ( $3 \mathrm{~min} ; 103 \mathrm{kPa}$ ) with $0 \%, 2 \%$, or $4 \%$ solutions of calcium chloride $\left(\mathrm{CaCl}_{2}\right.$ and then placed immediately at $0 \mathrm{C}$ or heat-treated at $38 \mathrm{C}$ for 4 days before storage at $0 \mathrm{C}$. Area of decay was determined by inoculating fruit after 6 months storage at $0 \mathrm{C}$ and measuring decay following 5 days at $20 \mathrm{C}$. Vertical bars represent SE of means. 


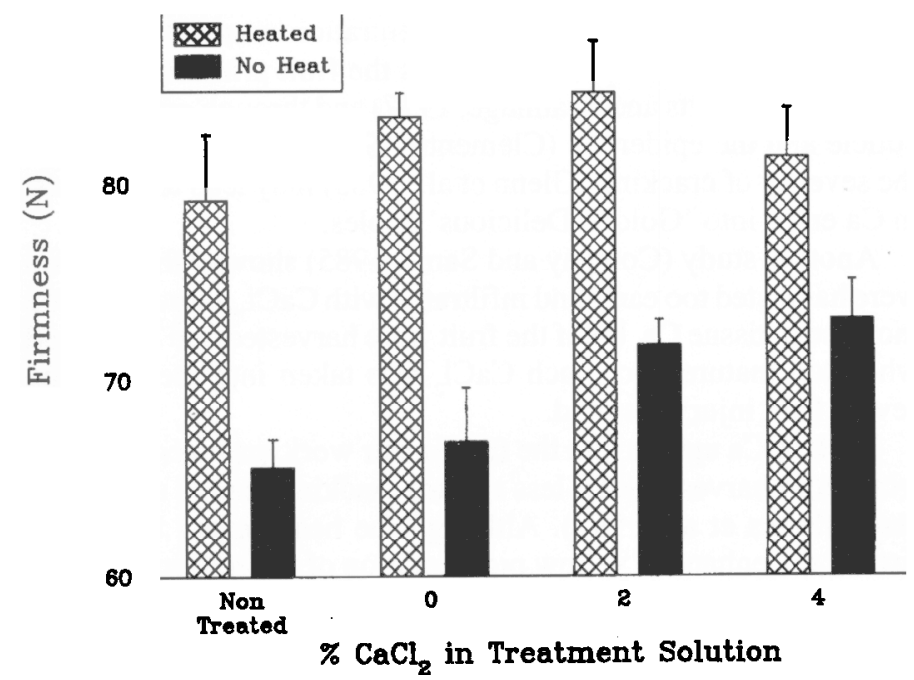

Fig. 2. Relationship between firmness and treatment of 'Golden Delicious' apples. Fruit were either nontreated or pressure-infiltrated ( $3 \mathrm{~min} ; 103 \mathrm{kPa}$ ) with $0 \%, 2 \%$, or $4 \%$ solutions of calcium chloride $\left(\mathrm{CaCl}_{2}\right.$ and then placed immediately at $0 \mathrm{C}$ or heat-treated at $38 \mathrm{C}$ for 4 days before storage at $0 \mathrm{C}$. Fruit firmness was determined after 6 months storage at 0C. Vertical bars represent SE of means.

$>40 \%$ less decay than in the control, and subsequent heat treatment (treatment 6) resulted in $60 \%$ less decay. Infiltration with $4 \%$ $\mathrm{CaCl}_{2}$ (treatment 7) also led to $60 \%$ less decay than in the control, but subsequent heat treatment (treatment 8) caused injury; this fruit was not tested for decay resistance.

Firmness. Fruit infiltrated with water (treatment 3) had the same EPT-1 firmness as the control fruit (treatment 1) (Fig. 2). Fruit infiltrated with either $2 \% \mathrm{CaCl}_{2}$ (treatment 5) or $4 \% \mathrm{CaCl}_{2}$ (treatment 7) was slightly firmer than the control. The heated fruit (treatments 2 and 4) were significantly freer, but infiltration with a $2 \%$ (treatment 6 ) or $4 \%$ (treatment 8 ) solution of $\mathrm{CaCl}_{2}$ before heat treatment had no effect on firmness.

These effects were confirmed in Instron-MT firmness profiles

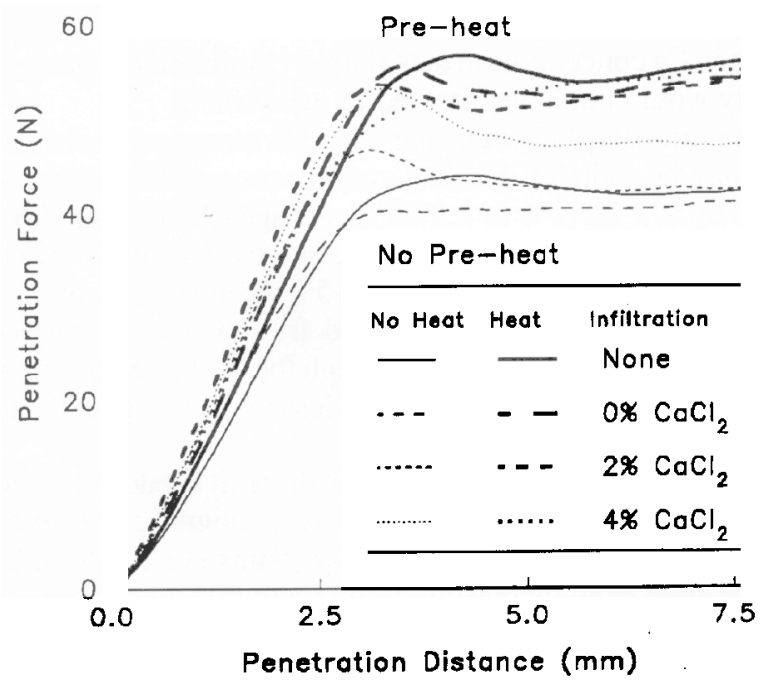

Fig. 3. Instron Magness-Taylor curves for 'Golden Delicious' apples. Fruit were either nontreated or pressure-infiltrated ( $3 \mathrm{~min} ; 103 \mathrm{kPa}$ ) with $0 \%, 2 \%$, or $4 \%$ solutions of calcium chloride $\left(\mathrm{CaCl}_{2}\right)$ and then placed immediately at $0 \mathrm{C}$ or heattreated at $38 \mathrm{C}$ for 4 days before storage at $0 \mathrm{C}$. Measurements were determined after 6 months storage at $0 \mathrm{C}$. Each curve represents the mean of 120 Instron Magness-Taylor measurements (three replications $\times 20$ apples $\times$ two sides).

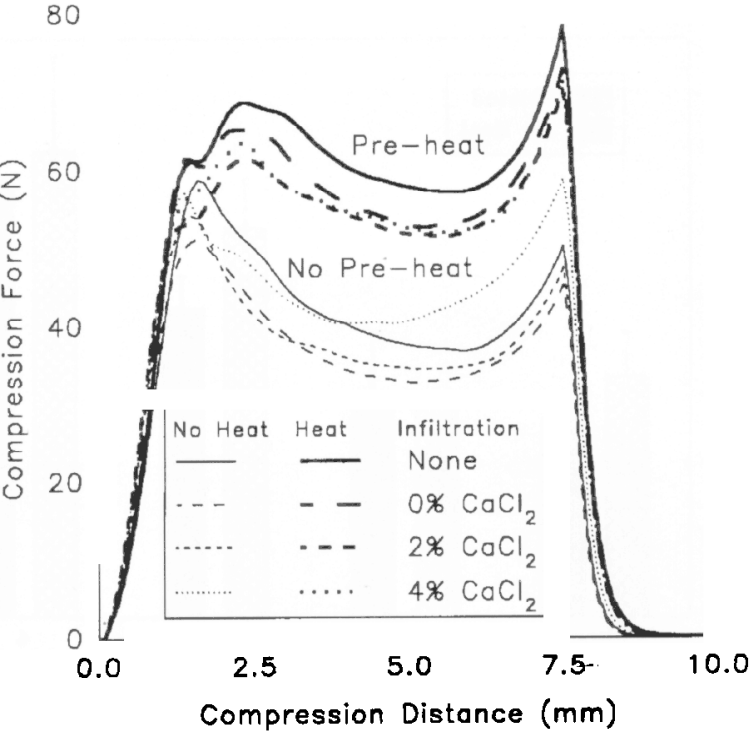

Fig. 4. Compression test curves for 'Golden Delicious' apples. Fruit were either nontreated or pressure-infiltrated ( $3 \mathrm{~min} ; 103 \mathrm{kPa}$ ) with $0 \%, 2 \%$, or $4 \%$ solutions of calcium chloride $\left(\mathrm{CaCl}_{2}\right)$ and then placed immediately at $0 \mathrm{C}$ or heat-treated at $38 \mathrm{C}$ for 4 days before storage at $0 \mathrm{C}$. Measurements were determined after 6 months storage at $0 \mathrm{C}$. Each curve represents the mean of 120 compression tests (three replications $\times 20$ apples $\times$ two sides).

(Fig. 3). All treatments that included preheating (treatments 2,4, 6 , and 8) were firmer than those that did not. Fruit treated with $2 \%$ or $4 \% \mathrm{CaCl}_{2}$ without heat (treatments 5 and 7) appeared as firm as the preheated fruit on the basis of maximum force, but showed a decline after initial failure, which was not seen in the other treatments.

In Instron compression tests (Fig. 4), preheated fruit had higher maximum force values than nonheated fruit. A second peak force following the rupture peak was seen only in the heat-treated apples, and could result in increased toughness, rather than increased firmness or crispness; but, sensory tests have not been done to confirm this hypothesis.

Color observation. Although heat-treated fruit were firmer,

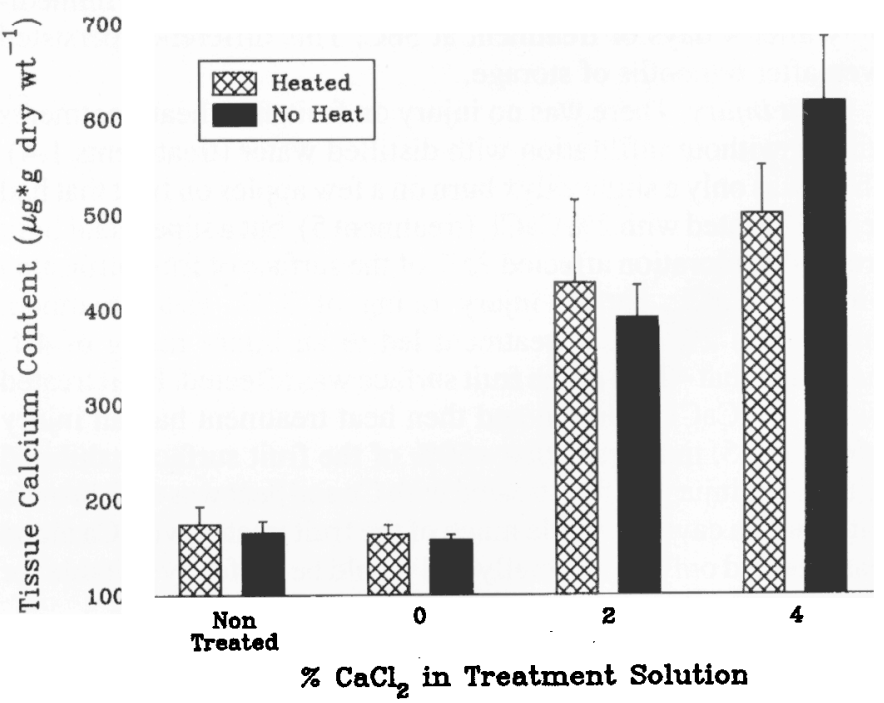

Fig. 5. Relationship between treatment and total tissue calcium content of 'Golden Delicious' apples. Fruit were either nontreated or pressure-infiltrated (3 min; 103 $\mathrm{kPa})$ with $0 \%, 2 \%$, or $4 \%$ solutions of calcium chloride $\left(\mathrm{CaCI}_{2}\right.$ and then placed immediately at $0 \mathrm{C}$ or heat-treated at $38 \mathrm{C}$ for 4 days before storage at $0 \mathrm{C}$. Total tissue $\mathrm{Ca}$ content was determined after 6 months storage at $0 \mathrm{C}$. Vertical bars represent SE of means. 


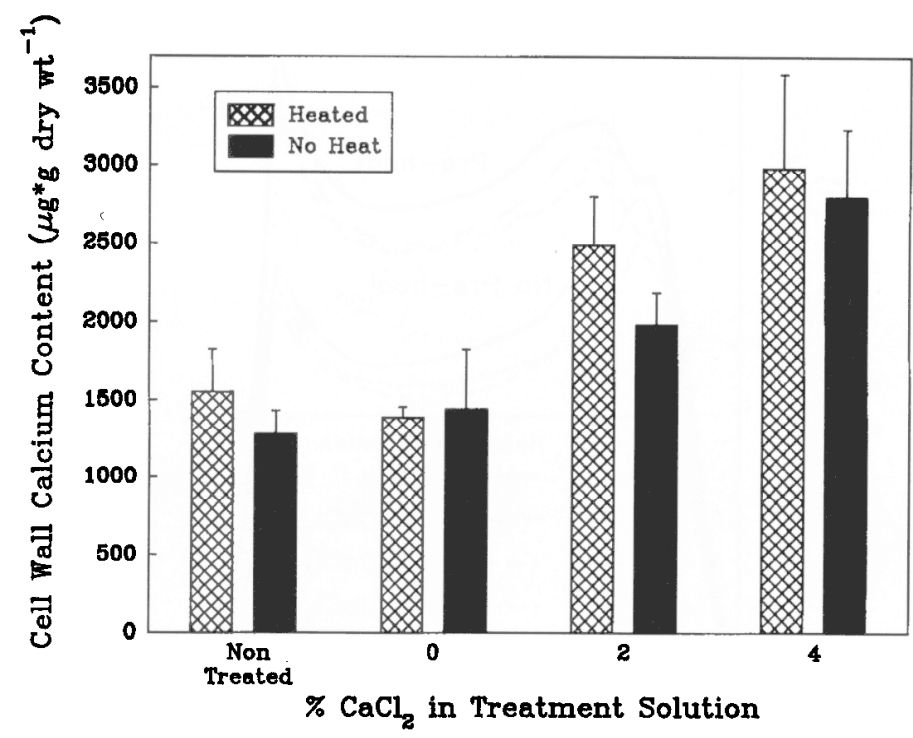

Fig. 6. Relationship between treatment and cell wall calcium content of 'Golden Delicious' apples. Fruit were either nontreated or pressure-infiltrated ( $3 \mathrm{~min} ; 103$ $\mathrm{kPa}$ ) with $0 \%, 2 \%$, or $4 \%$ solutions of calcium chloride $\left(\mathrm{CaCl}_{2}\right)$ and then placed immediately at $0 \mathrm{C}$ or heat-treated at $38 \mathrm{C}$ for 4 days before storage at $0 \mathrm{C}$. Cell wall $\mathrm{Ca}$ content was determined after 6 months storage at $0 \mathrm{C}$. Vertical bars represent SE of means.

visually determined background color change from green to yellow was enhanced.

Calcium content. As expected, Infiltration with a $2 \%$ or $4 \%$ $\mathrm{CaCl}_{2}$ solution resulted in fruit with a higher $\mathrm{Ca}$ concentration (treatments 5-8) than in noninfiltrated fruit (treatments 1-4) (Fig. 5).

Cell wall-bound $\mathrm{Ca}$ also increased as the concentration of $\mathrm{CaCl}_{2}$ in the treatment solution increased (Fig. 6). Heat treatment, however, did not increase the amount of $\mathrm{Ca}$ associated with the cell wall.

Polyamine content. The spermidine or spermine concentrations in fresh apple tissue and in the cell wall were similar for heated and nonheated fruit (data not shown). However, putrescine levels in the fresh tissue were higher in the nonheated $\left(16.7 \mathrm{nmol} \cdot \mathrm{g}^{-1}\right.$ fresh weight) than in heated $\left(5.1 \mathrm{nmol} \cdot \mathrm{g}^{-1}\right.$ fresh weight $)$ fruit immediately after 4 days of treatment at $38 \mathrm{C}$. This difference persisted even after 6 months of storage.

Fruit injury. There was no injury on fruit after heat treatments with or without infiltration with distilled water (treatments 1-4). There was only a slight calyx burn on a few apples on fruit that had been infiltrated with $2 \% \mathrm{CaCl}_{2}$ (treatment 5), but a superificial light brown discoloration affected $25 \%$ of the surface of fruit infiltrated with $4 \% \mathrm{CaCl}_{2}$, for an injury rating of 3.77 . Heat treatment following a $2 \% \mathrm{CaCl}_{2}$ treatment led to an injury rating of 4.1 , indicating that $\approx 20 \%$ of the fruit surface was affected. Fruit treated with a $4 \% \mathrm{CaCl}_{2}$ solution and then heat treatment had an injury rating of 2.5 , indicating that $\approx 50 \%$ of the fruit surface exhibited injury. The injury on fruit treated with $\mathrm{Ca}$ and heat was dark brown, with sunken cavities, while much of the fruit treated with $\mathrm{Ca}$ alone was affected only superficially and would be perfectly suitable for processing.

\section{Discussion}

The results show that heat treatment before storage maintains fruit firmness and reduces decay caused by $B$. cinerea by $\approx 30 \%$, which is similar to the decay reduction observed with $P$. expansum in earlier work (Sams et al., 1993). Calcium chloride solution infiltration had only a slight effect on maintaining firmness, presumably because $\mathrm{Ca}$ tissue concentration was not increased sufficiently. Calcium probably enters the fruit primarily through the lenticels (Betts and Bramlage, 1977) and through cracks in the cuticle and the epidermis (Clements, 1935). Annual variation in the severity of cracking (Glenn et al., 1985) may lead to variation in Ca entry into 'Golden Delicious' apples.

Another study (Conway and Sams, 1985) showed that, if fruit were harvested too early and infiltrated with $\mathrm{CaCl}_{2}$, there was little increase in tissue $\mathrm{Ca}$, but if the fruit were harvested and infiltrated when too mature, too much $\mathrm{CaCl}_{2}$ was taken into the fruit and severe fruit injury resulted.

Lack of $\mathrm{Ca}$ uptake into the fruit in our work may have resulted from early harvest and/or less surface cracking than in a previous study (Sams et al., 1993). Although the heat-treated fruit were firmer, the enhanced yellow pigmentation of the peel in the heattreated fruit compared to the controls gave the impression that the heated fruit were riper, a condition observed-in a previous study (Lurie and Klein, 1992).

The firmness profile comparing heat-treated and nontreated fruit indicates that the heat-treated fruit are firmer, but in a manner that makes them texturally "harder" or "tougher" and less crisp than nontreated fruit. The texture profile curves illustrate the need for measuring more than just Magness-Taylor maximum force in doing postharvest quality studies on fruit.

The mechanism by which increased tissue $\mathrm{Ca}$ reduces decay and maintains firmness is hypothesized to be related to $\mathrm{Ca}$ ions in the cell wall (Demarty et al., 1984). Cell wall pectins are composed primarily of four-linked galacturonosyl residues, with varying amounts of two-linked rhamnosyl residues interspersed in the chain (Preston, 1979). The stability of the cell wall maybe related to the cooperative binding of polygalacturonate chains with $\mathrm{Ca}$ ions (Grant et al., 1973; Knee, 1978), making the cell wall of the fruit less accessible to enzymes that cause softening or to cell walldegrading enzymes produced by fungal pathogens. Increasing the $\mathrm{Ca}$ content of apple cell walls has been shown to inhibit maceration by polygalacturonase produced by $P$. expansum (Conway et al., 1988). To reduce apple fruit decay caused by $P$. expansum by more than $50 \%$, fruit tissue Ca concentration must be increased to 1200 $1500 \mu \mathrm{g} \mathrm{Ca} / \mathrm{g}$ dry weight, but lower concentrations may inhibit progress of $B$. cinerea (Conway et al., 1991). In this study, an increase in Ca concentration to $600 \mu \mathrm{g} \cdot \mathrm{g}^{-1}$ inhibited $B$. cinerea, but probably would not have affected $P$. expansum.

The relationship between maintained firmness and resistance to decay may be indirect. Similar maintenance of firmness can be attained by low $\mathrm{O}_{2}\left(1 \%\right.$ to $\left.1.5 \% \mathrm{O}_{2}\right)$ storage (Anderson, 1967) or Ca treatment, but the area of decay caused by $P$. expansum in low$\mathrm{O}_{2}$ - stored fruit was reduced by only $15 \%$, while Ca-treated apples had $50 \%$ less decay than nontreated fruit (Conway and Sams, 1984). Similarly, in this study, although the heat treated fruit were slightly firmer, the area of decay was less in the Ca- than the heattreated fruit.

While the optimum amount of $\mathrm{Ca}$ in the fruit needed to decrease decay and maintain firmness is $\approx 1200 \mu \mathrm{g} \cdot \mathrm{g}^{-1}$, significantly exceeding this amount resulted in fruit injury (Sams et al., 1993). Little injury resulted from increasing tissue $\mathrm{Ca}$ to $600 \mu \mathrm{g} \cdot \mathrm{g}^{-1}$, but, when this increase is followed by heat treatment, extensive injury developed. Heat treatment following $\mathrm{Ca}$ infiltration, then, results in fruit that are much more easily injured by $\mathrm{Ca}$ and at a $\mathrm{Ca}$ concentration much lower than would affect nonheat-treated fruit.

The mechanism by which heat treatment reduces decay and maintains firmness through effects on the cell wall has not been explained satisfactorily. Heat inactivation of synthesis of pectin- 
degrading enzymes was considered a possible mechanism, and analysis of 'Golden Delicious' fruit following storage showed significantly lower levels of soluble pectin in juice of heat-treated fruit than controls (Porritt and Lidster, 1978). In 'Spartan' apples, however, differences in soluble pectin levels were not significant, even though both cultivars were firmer as a result of heat treatment. Klein and Lurie (1990) showed that, during shelf life, the insoluble pectin fraction remained larger in heat-treated than in nonheated apples, and that the water-soluble and $\mathrm{Ca}$ pectate fractions did not increase as much.

Heat treatment may inhibit protein synthesis required for cell wall degradation and ethylene synthesis (Lurie and Klein, 1990). In a study comparing the effects of heat and $\mathrm{Ca}$ on firmness, heat treatment for 4 days at $38 \mathrm{C}$ before storage had the greatest effect on firmness (Klein et al., 1990). The Ca treatment was applied by dipping in a $2 \% \mathrm{CaCl}_{2}$ solution at $38 \mathrm{C}$, and may not have increased $\mathrm{Ca}$ concentration of the cortex enough to influence firmness. If the Ca concentration is increased above the $1200 \mu \mathrm{g} . \mathrm{g}^{-1}$ range, Ca maintained firmness better than heat treatment (Sams et al. 1993).

The heat treatment had little effect on polyamine levels in either tissue or cell walls with the exception of putrescine, The higher putrescine concentrations in the nonheated than in the heated fruit tissue immediately after heat treatment and following 6 months of storage at $0 \mathrm{C}$ were probably a result of low-temperature stress. The heated fruit were placed at $38 \mathrm{C}$ prior to storage, so may not have been affected by this stress that fruit placed immediately into $0 \mathrm{C}$ storage experienced, or heat treatment inhibited putrescine accumulation.

\section{Literature Cited}

Abbott, J. A., D.R. Massie, and A.E. Watada. 1982. The use of a computer with an Instron for textural measurements. J. Texture Stud. 13:413-422. Abbott, J. A., A.E. Watada, and D.R. Massie. 1984. Sensory instrument measurement of apple texture. J. Amer. Soc. Hort. Sci. 109:221-228.

Anderson, R.E. 1967. Experimental storage of Eastern grown 'Delicious' apples in various controlled atmospheres. Proc. Amer. Soc. Hort. Sci. 91:810-820.

Betts, H.A. and W .J. Bramlage. 1977. Uptake of calcium by apples from postharvest dips in calcium chloride solutions. J. Amer. Soc. Hort. Sci. 102:785-788.

Clements, H.F. 1935. Morphology and physiology of the pome lenticels of Pyrus malus. Bot. Gaz. 97:101-117.

Conway, W. S., K.C. Gross, C.D. Boyer, and C.E. Sams. 1988. Inhibition of Penicillium expansum polygalacturonase activity by increased apple cell wall calcium. Phytopathology 78: 1052-1055.

Conway, W.S. and C.E. Sams. 1983. Calcium infiltration of Golden Delicious apples and its effect on decay. Phytopathology 73:1068-1071.

Conway, W.S. and C.E. Sams. 1984. Possible mechanisms by which postharvest calcium treatment reduces decay in apples. Phytopathology 74:208-210.

Conway, W.S. and C.E. Sams. 1985. Influence of fruit maturity on the effect of postharvest calcium treatment on decay of Golden Delicious apples. Plant Dis. 69:42-44.

Conway, W. S., C.E. Sams, J.A. Abbott, and B.D. Bruton. 1991. Postharvest calcium treatment of apple fruit to provide broad-spectrum protection against postharvest pathogens. Plant Dis. 75:620-622.

Demarty, M., C. Morvan, and M. Thellier. 1984. Calcium and the cell wall. Plant Cell Environ. 7:441-448.

Glenn, G. M., B.W. Poovaiah, and H.P. Rasmussen. 1985. Pathways of calcium penetration through isolated cuticles of 'Golden Delicious' apple fruit. J. Amer. Soc. Hort. Sci. 110:166-171.

Grant, G. T., E.R. Morris, D.A. Rees, P.J.C. Smith, and D. Thorn. 1973. Biological interactions between polysaccharides and divalent cations: The egg-box model. FEBS Lett. 32: 195-198.

Huber, D.J. 1991. Acidified phenol alters tomato cell wall pectin solubility and calcium content. Photochemistry 30:2523-2527.

Klein, J.D. and S. Lurie. 1990. Prestorage heat treatment as a means of improving poststorage quality of apples. J. Amer. Soc. Hort. Sci. 115: 265-269.

Klein, J.D., S. Lurie, and R. Ben-Arie. 1990. Quality and cell wall components of 'Anna' and 'Granny Smith' Apples treated with heat, calcium, and ethylene. J. Amer. Soc. Hort. Sci. 115:954-958.

Knee, M. 1978. Properties of polygalacturonate and cell cohesion in apple fruit cortical tissue. Phytochemistry 17: 1257-1260.

Kramer, G.F. and C.Y. Wang. 1989. Correlation of reduced chilling injury and oxidative damage with increased polyamine levels in zucchini squash. Physiol Plant 76:479-484.

Kramer, G. F., C.Y. Wang, and W.S. Conway. 1989. Correlation of reduced softening and increased polyamine levels during low-oxygen storage of 'McIntosh' apples. J. Amer. Soc. Hort. Sci. 114:942-946.

Kramer, G. F., C.Y. Wang, and W.S. Conway. 1991. Inhibition of softening by polyamine application in 'Golden Delicious' and 'McIntosh' apples. J. Amer. Soc. Hort. Sci. 116:813-817.

Liu, F.W. 1978. Modification of apple quality by high temperature. J. Amer. Soc. Hort. Sci. 103:730-732.

Lurie, S. and J.D. Klein. 1990. Heat treatment of ripening apples: Differential effects on physiology and biochemistry. Physiol. Plant. 78:181-186.

Lurie, S. and J.D. Klein. 1992. Calcium and heat treatments to improve storability of 'Anna' apples. HortScience 27:36-39.

Porritt, S.W. and P.D. Lidster. 1978. The effect of pre-storage heating on ripening and senescence of apples during cold storage. J. Amer. Soc. Hort. Sci. 103:584-587.

Preston, R.D. 1979. Polysaccharide formation and cell wall function. Annu. Rev. Plant Physiol. 30:55-78.

Sams, C.E. and W.S. Conway. 1984. Effect of calcium infiltration on ethylene production, respiration rate, soluble polyuronide content, and quality of 'Golden Delicious' apple fruit. J. Amer. Soc. Hort. Sci. 109:53-57.

Sams, C. E., W.S. Conway, J.A. Abbott, R.J. Lewis, and N. Ben-Shalom. 1993. Firmness and decay of apples following postharvest pressure infiltration of calcium and heat treatment. J. Amer. Soc. Hort. Sci. 118:623-627.

Tong, C.B.S. and K.C. Gross. 1990. Stimulation of ethylene production by a cell wall component from mature green tomato fruit. Physiol. Plant. 80:500-506. 